\title{
Upaya Pencegahan Penyakit Akibat Kerja Pada Perawat di Rumah Sakit
}

\author{
Eka Rosliani Nasution \\ ekaroslianinasution1303@gmail.com
}

\begin{abstract}
Abstrak
Tenaga kesehatan berperan dalam meningkatkan derajat kesehatan masyarakat dan berhak mendapatkan jaminan kesehatan dan keselamatan kerja. Penelitian sebelumnya melaporkan kecelakaan kerja yang sering terjadi di rumah sakit adalah tertusuk jarum, teriris pisau, terluka dan terpercik cairan tubuh. Kejadian tersebut banyak yang belum terlaporkan karena padatnya jadwal pelayanan kesehatan dan rendahnya persepsi terhadap risiko terpapar infeksi. Rendahnya persepsi dan tingginya risiko kejadian kecelakaan kerja menjadi tujuan penelitian ini dilakukan untuk mengetahui hubungan antara persepsi tenaga kesehatan terhadap penggunaan alat pelindung diri dengan kejadian kecelakaan akibat kerja. Pengetahuan dan sikap Perawat dalam penggunaan alat pelindung diri pada saat melaksanakan tindakan keperawatan akan mengurangi resiko terjadinya pemularan infeksi di rumah sakit. Penelitian ini bertujuan untuk melihat hubungan pengetahuan dan sikap perawat tentang APD dengan tindakan pencegahan infeksi di ruang Intencif Care Unit (ICU). Untuk faktor pemungkin kebijakan pencegahan PAK dan ketersediaan fasilitas kesehatan yang layak sudah disediakan. Sementara itu dukungan pimpinan dan petugas kesehatan sudah berjalan. Semuanya ini membentuk perilaku pencegahan PAK informan yang terlihat dari berbagai kegiatan pencegahan dan penanganan PAK. Namun demikian pelaksanaan pencegahan PAK tidak berjalan sepenuhnya karena faktor kelalaian, ceroboh, kurang sadar, kurang peduli, niat yang kurang dari individu, dan tidak berperilaku hidup sehat. Selain itu kebijakan juga sering tidak update, tidak ada sanksi, serta masih dirasakan kurangnya dukungan perusahaan dan masalah komunikasi bahasa dengan petugas kesehatan.
\end{abstract}

\section{Latar Belakang}

Kecelakaan kerja merupakan salah satu permasalahan yang sering terjadi di dunia industri. Di Indonesia penyebab tingginya angka kecelakaan kerja salah satunya karena kurang penerapan K3. Tingginya angka kecelakaan kerja di Indonesia, membawa pemerintah pada misi agar seluruh perusahaan di Indonesia berbasis Kesehatan dan Keselamatan Kerja (K3) pada tahun 2015.

Kecelakaan kerja di kalangan petugas kesehatan dan non kesehatan kesehatan di Indonesia belum terekam dengan baik. Sebagai faktor penyebab, sering terjadi karena kurangnya kesadaran pekerja dan kualitas serta keterampilan pekerja yang kurang memadai. Menurut International Labour Organitation (ILO) setiap tahun sebanyak dua juta pekerja meninggal dunia karena kecelakaan kerja yang disebabkan oleh faktor kelelahan.

Penyakit akibat kerja (PAK) merupakan salah satu bagian dari masalah kesehatan yang berkaitan dengan pekerjaan seseorang dan dipengaruhi oleh berbagai faktor disekitarnya.

Keselamatan sangat dibutuhkan oleh perawat saat bekerja. Keselamatan merupakan salah satu kebutuhan dasar manusia yang harus dipenuhi. Manajemen rumah sakit bertanggung jawab untuk membuat program manajemen risiko yang berkelanjutan untuk mengurangi dan mengidentifikasi kejadian yang tidak diinginkan dan risiko-risiko keselamatan lainnya pada pasien dan staf rumah 
sakit. Perawat seringkali kurang peduli terhadap bahaya di tempat kerja dan dalam melakukan upaya proteksi diri meskipun perawat tahu hal tersebut dapat membahayakan keehatan dan nyawa perawat.

Penyakit Akibat Kerja adalah penyakit yang disebabkan oleh pekerjaan dan lingkungan kerja. Faktor risiko PAK antara lain: Golongan fisik, kimiawi, biologis atau psikososial di tempat kerja. Faktor tersebut di dalam lingkungan kerja merupakan penyebab yang pokok dan menentukan terjadinya penyakit akibat kerja. Faktor lain seperti kerentanan individual juga berperan dalam perkembangan penyakit di antara pekerja yang terpajan.

Selain potensi bahaya berupa penyakit infeksi yang umumnya berasal dari pasien, rumah sakit juga mempunyai potensi bahaya lain yang mempengaruhi situasi dan kondisi di rumah sakit yaitu peledakan, kebakaran, kecelakaan yang berhubungan dengan instalasi listrik, radiasi, bahan bahan kimia berbahaya, gas anestesi, gangguan psikososial, dan ergonomi (Aditama, 2006).

Kejadian infeksi yang tinggi di rumah sakit merupakan indikator pentingnya suatu usaha pengendalian infeksi dengan menerapkan standar kewaspadaan infeksi (Standard precaution). Standard Precaution pada dasarnya merupakan transformasi dari universal precaution, yaitu suatu bentuk precaution pertama yang bertujuan untuk mencegah infeksi nosokomial (Kathryn, 2004).

Dalam meningkatkan upaya tindakan pencegahan infeksi, diperlukan pengetahuan dan sikap perawat dalam penggunaan alat pelindung diri (APD) agar terhindar dari risiko penularan penyakit baik dari pasien ke perawat maupun sesama pasien.

Perilaku perawat dalam bekerja dipandu melalui pedoman kerja. Selain standar operasional prosedur (SOP) dan standar asuhan keperawatan (SAK) sebagai pedoman perawat dalam bekerja, panduan keselamatan perawat diperlukan untuk memandu perawat berperilaku aman dan selamat dalam bekerja. Oleh karena itu, protokol keamanan untuk perawat dan pasien harus diikuti dan dipraktikkan dengan baik.

Ruang Instalasi Gawat Darurat (IGD) merupakan bagian dari pelayanan kesehatan yang dibutuhkan oleh penderita dalam waktu segera untuk keselamatan hidupnya. Di instalasi gawat darurat setiap saat terdapat kasus dengan berbagai tingkat kegawatan yang harus segera mendapat pelayanan. Petugas medis sebagai tenaga kesehatan yang kontak dengan pasien harus selalu cepat, tepat, dan cermat untuk mencegah kematian dan kecacatan. Dalam situasi tersebut ruang IGD dapat memungkinkan banyak terjadinya kecelakaan kerja pada petugas medis. Petugas medis di ruang IGD antara lain perawat serta dokter. Perawat merupakan petugas medis pertama yang menangani pasien sebelum dokter. Dengan beban kerja yang tinggi di ruang IGD dapat memungkinkan terjadinya stress kerja pada perawat IGD (Kasmarani, 2012). Selain stress kerja, keluhan muskuloskeletal juga sering dialami oleh perawat IGD (Zurikah, 2016). Berdasarkan hal tersebut maka perawat lebih berisiko tinggi terjadinya penyakit akibat kerja di ruang IGD bila dibandingkan dengan dokter.

\section{Metode}

Metode penulisan yang digunakan ialah dengan metode deskriptif. Dimana dilakukan dengan teknik pengumpulan data atau informasi dengan melakukan analisis, eksplorasi, kajian bebas (literatur review) yang relevan yang berfokus pada tema yaitu bagimana upaya kesehatan keselamatan kerja dan pencegahan penyakit akibat kerja pada perawat.

Adapun sumber yang digunakan dalam penulisan ini menggunakan sumber dari jurnal dengan memasukkan kata kunci upaya kesehatan keselamatan kerja dan pencegahan penyakit akibat 
kerja pada perawat. Adapun referensi dari jurnal yang saya gunakan merupakan jurnal yang diterbitkan pada 8 tahun terakhir ( dengan tahun paling tua 2012).

\section{Hasil}

Berdasarkan hasil analisis dan kajian bebas dari beberapa jurnal yang sesuai denan topik yang di bahas. Maka dapat diperoleh bahwa bahwa pemicu penyakit karena kerja yang dapat menyebabkan penyakit akibat kerja (PAK) pada perawat yang terjadi di Rumah Sakit (RS), umumnya berkaitan dengan:

1. Faktor biologi

2. Faktor kimia

3. Faktor ergonomi

4. Faktor fisik dalam dosis kecil yang terus-menerus

5. Faktor psikologis

Upaya pencegahan menurut standar K3 yaitu Melakukan pencatatan kejadian Kecelakaan Akibat Kerja (KAK) sesuai dengan prosedur yang ditetapkan oleh petugas K3 :

1. Perlu dilakukan peningkatan terhadap penerapan pelayanan kesehatan kerja terutama pada pemeriksaan kesehatan khusus, pengobatan dan perawatan bagi penderita yang sakit, pemantauan lingkungan kerja serta ergonomi dan evaluasi pencatatan serta pelaporan kepada Direktur Rumah Sakit.

2. Perlu diadakan pemeriksaan kesehatan sebelum bekerja seperti pemeriksaan paru-paru, laboratorium maupun pemeriksaan secara fisik terhadap perawat IGD maupun tenaga medis yang lain.

3. Perlu diadakan kegiatansurvelans kerja seperti pemetaan tempat keja berdasarkan risiko bahayanya.

4. Perlu diadakan penyesuaian terhadap peralatan kerja SDM Rumah Sakit seperti mengidentifikasi ergonomi terhadap peralatan kerja dan risiko peralatan kerjanya.

Seperti yang tercantum dalam Kepmenkes RI No. 1087 Tahun 2010 tentang standart kesehatan dan keselamatan kerja (K3) di Rumah Sakit bahwa penyesuaian terhadap peralatan kerja SDM dikatakan sudah diterapkan apabilah telah melakukan :

1. Identifikasi dan penilaian risiko ergonomi terhadap perlatan kerja dan SDM Rumah Sakit.

2. Membuat program pelaksanaan kegiatan, mengevaluasi dan mengendalikan risiko ergonomi.

Tujuan diterapkannya K3RS adalah terciptanya cara kerja, lingkungan kerja yang sehat, aman, nyaman, dan dalam rangka meningkatkan derajat kesehatan karyawan RS. Pengetahuan K3RS yang baik diharapkan mampu menekan angka kecelakaan kerja karena individu tersebut dapat menerapakan tindakan yang sesuai dengan pengetahuan K3 yang dimilikinya.

\section{Pembahasan}

Penyebab kecelakaan atau cedera salah satunya adalah kebiasaan dimana terdapat suatu keadaan lingkungan tidak aman (unsafe condi- tion) atau tindakan yang tidak memenuhi keselamatan (unsafe act). Seringkali kecelakaan merupakan kombinasi dari kedua faktor tersebut. Pada penelitian ini kejadian cedera pada perawat bisa terjadi karena dipengaruhi oleh tindakan yang tidak memenuhi keselamatan (unsafe act) dalam hal ini adalah kepatuhan dalam menerapkan pedoman keselamatan kerja. 


\section{Pengetahuan Pekerja tentang Penyakit Akibat Kerja (PAK)}

Definisi PAK berdasarkan pandangan informan merupakan penyakit yang berkaitan dengan segi pekerjaan, berkembang, punya efek ke belakang hari, ada paparan tidak langsung yang dapat menyebabkan kecelakaan kerja, dan bisa disebabkan oleh kesalahan diri sendiri atau ceroboh. Penyakit-penyakit yang dikaitkan dengan PAK oleh para informan diantaranya adalah penyakit akibat kebisingan, tidak pakai masker, getaran dan lingkungan, malaria, pernafasan, dan kecelakaan kerja.

\section{Sikap Pencegahan Penyakit Akibat Kerja}

Peran serta para pekerja dalam mencegah PAK merupakan komponen sikap. Para informan sudah mempunyai pengetahuan langkah-langkah mencegah PAK, walaupun masih saja ada yang tidak patuh terhadap prosedur pencegahan PAK di lokasi kerja. Menurut pengetahuan para informan langkah terbanyak yang harus dilakukan adalah mengikuti prosedur safety, diikuti jangan ada kelalaian, ada niat dari diri sendiri, dan adanya pola hidup sehat.

\section{Kebutuhan Pencegahan Penyakit Akibat Kerja}

Kebutuhan yang diperlukan untuk mencegah PAK adalah meningkatkan perilaku hidup bersih dan mematuhi pencegahan PAK. Berdasarkan informasi informan maka kebutuhan yang diperlukan untuk mencegah PAK di lokasi kerja pada umumnya adalah perilaku hidup sehat

Perilaku pekerja dalam melaksanakan pencegahan PAK masih harus diperbaiki. Hasil analisis menunjukkan kelalaian, kecerobohan atau kurang sadar, pengabaian atau tidak patuh terhadap safety dari individu (informan), ditemukannya pimpinan yang kurang perhatian, ketidakpuasan pelayanan petugas kesehatan, dan keterlambatan laporan sakit dari para pekerja merupakan hal yang harus diperbaiki untuk meningkatkan kesehatan kerja yang mendukung pencegahan PAK. Kebijakan kesehatan kerja adalah hal penting yang harus ada untuk menjadi pedoman yang diikuti oleh para pekerja. Adanya kebijakan kesehatan dan keselamatan kerja dapat mengurangi ketimpangan kesehatan kerja. Kemudian, pelaksanaan dari kebijakan kesehatan tersebut adalah langkah penting berikutnya yang harus dijalankan.

Kehidupan manusia tidak pernah terlepas dari pekerjaan, apapun jenis pekerjaan selalu dilakukan dalam rangka memenuhi kebutuhan sehari-hari, mulai dari pekerjaan Liza Salawati, Penyakit Akibat Kerja dan Pencegahan berisiko rendah hingga berisiko tinggi. Disamping itu pemahaman dan penerapan keselamatan dan kesehatan kerja (K3) masih kurang di perhatikan oleh pekerja formal maupun informal. Pada hal faktor K3 sangat penting dan harus diperhatikan oleh pekerja dan hal ini menjadi tanggung jawab bersama, perlu adanya kerja sama antara pemerintah, perusahaan dan pekerja agar terhindar dari Kecelakaan Akibat Kerja (KAK) dan Penyakit Akibat Kerja (PAK). Keselamatan dan Kesehatan Kerja merupakan upaya perlindungan tenaga kerja dari bahaya, penyakit dan kecelakaan akibat kerja maupun lingkungan kerja. Penegakan diagnosis spesifik dan sistem pelaporan penyakit akibat kerja penting dilakukan agar dapat mengurangi dan atau bebas dari kecelakaan kerja dan penyakit akibat kerja yang pada akhirnya dapat meningkatkan efisiensi dan produktivitas kerja.

\section{Tindakan pencegahan Penyakit Akibat Kerja}

Menurut Tietjen dkk (2004), Sebagian besar infeksi ini dapat dicegah dengan strategi yang telah tersedia secara relatif murah, yaitu :

1. Mentaati praktek pencegahan infeksi yang

dianjurkan, terutama kebersihan dan kesehatan tangan serta pemakaian sarung tangan, 
2. Memperhatikan dengan seksama proses yang telah terbukti bermanfaat untuk dekontaminasi dan pencucian peralatan dan benda lain yang kotor, diikuti dengan sterilisasi atau disinfeksi tingkat tinggi; dan

3. Meningkatkan keamanan dalam ruang operasi dan area beresiko tinggi lainnya dimana kecelakaan perlukaan yang sangat serius dan paparan pada agen penyebab infeksi sering terjadi. Tidak semua infeksi nosokomial dapat dicegah. Contohnya, beberapa merupakan pengaruh bertambahnya usia, penyakit kronis seperti diabetes yang tidak terkontrol, penyakit ginjal berat, kekurangan gizi berat, perawatan dengan obat-obatan tertentu (separti antimikrobia, kortikosteroid, dan agen-agen lain yang dapat menurunkan imunisasi), bertambahnya dampak AIDS (misalnya, infeksi oportunistik) dan radiasi. Tietjen dkk (2004).

\section{Alat Pelindung Diri (APD)}

Alat pelindung diri merupakan peralatan yang digunakan tenaga kesehatan untuk melindungi diri dan mencegah infeksi nosokomial. Tujuan penggunaan APD untuk melindungi kulit dan selaput lendir tenaga kesehatan dari pajanan semua cairan tubuh dari kontak langsung dengan pasien (Depkes, 2003) APD perawat ketika praktek terdiri dari sarung tangan, alat pelindung wajah, penutup kepala, gaun pelindung atau apron, alas kaki atau sepatu (potter \& perry, 2005).

\section{Sarung tangan}

Pemakaian sarung tangan merupakan bagian penting dari standar precaution bagi perawat yang sering berinteraksi dengan pasien maupun alat-alat yang terkontaminasi. Sarung tangan dapat membantu perawat untuk melindungin tangan dari kontak dengan darah, semua jenis cairan tubuh, sekret, kulit yang tidak utuh, selaput lendir pasien dan benda yang terkontaminasi (Depkes RI, 2003). Hal yang perlu diperhatikan dalam penggunaan sarung tangan (Depkes RI, 2003) :

- Mencuci tangan dengan sabun sebelum dan sesudah menggunakan sarung tangan,

- Mengganti sarung tangan jika berganti pasien atau sobek,

- Mengganti sarung tangan segera setelah melakukan tindakan,

- Menggunakan sarung tangan saat menggunakan alat nonkontaminasi,

- Menggunakan satu sarung tangan untuk satu prosedur tindakan,

- Menghindari kontak dengan benda-benda selain dalam tindakan,

- Menghindari penggunaan atau mendaur ulang kembali sarung tangan sekali pakai.

2. Alat pelindung wajah Alat pelindung wajah merupakan peralatan

wajib perawat untuk menjaga keamanan dirinya dalam menjalankan asuhan keperawatan. Alat pelindung diri wajah dapat melindungi selaput lendir dibagian mulut, hidung dan mata perawat terhadap resiko percikan darah maupun cairan tubuh manusia. Alat pelindung wajah terdiri dari masker dan kacamata pelindung (Depkes,2003). Kedua jenis alat pelindung diri tersebut dapat digunakan terpisah maupun bersamaan sesuai dengan jenis tindakan.

Masker bagian alat pelindung muka khususnya untuk melindungi mulut dan hidung perawat ketika berinteraksi dengan pasien. Masker dianjurkan untuk selalu digunakan perawat ketika 
melakukan tindakan dengan semua pasien khususnya pasien TB. (Depkes, 2003). Hal ini diharapkan mampu melindungi perawat terhadap penularan melalui udara. Secara umum masker dibagi menjadi dua jenis yaitu masker standar dan masker khusus.Beberapa hal yang perlu diperhatikan ketika menggunakan masker ( WHO, 2004):

1. Memasang masker sebelum memasang sarung tangan,

2. Tidak dianjurkan menyentuh masker ketika menggunakannya, Mengganti masker ketika kotor dan lembab,

4. Melepas masker dilakukan setelah melepas sarung tangan dan cuci tangan,

5. Tidak membiarkan masker menggantung dileher,

6. Segera melepaskan masker dilakukan jika tidak digunakan

7. Tidak dianjurkan menggunakan kembali masker sekali pakai.

3. Penutup kepala Penutup kepala sebagai bagian dari standard

Precaution memilikin fungsi dua arah. Fungsi pertama, penutup kepala membantu mencegah terjadinya percikan darah maupun cairan pasien pada rambut perawat. Selain itu, penutup kepala dapat mencegah jatuhnya mikroorganisme yang ada di rambut maupun kulit kepala ke area steril (Depkes, 2003). Kedua fungsi tersebut sangat penting untuk diperhatikan oleh perawat.

4. Gaun pelindung Gaun pelindung atau baju kerja atau

Celemek dapat memberikan manfaat bagi perawat untuk melindungi kulit dan pakaian dari kontaminasi cairan tubuh pasien. Gaun pelindung wajib digunakan ketika melakukan tindakan irigasi, menangani pasien dengan perdarahan, melakukan pembersihan luka, maupun tindakan lainnya yang terpapar dengan cairan tubuh pasien (Depkes, 2003). Gaun pelindung terdiri dari beberapa macam berdasarkan pada kegunaannya, Terdapat dua jenis gaun pelindung yaitu gaun pelindung steril dan non steril (Depkes, 2003).

Perawat sebagai pemberi asuhan keperawatan perlu mengetahui penggunaan gaun pelindung secara benar. Penggunaan gaun pelindung secara benar dapat melindungi perawat dari bahaya infeksi. Hal-hal yang perlu diperhatikan perawat dalam penggunaan gaun pelindung meliputi (Rosdahl \&Merry, 2008):

1. Bagian dalam gaun adalah bersih dan bagian luarnya adalah yang nantinya harus dijaga (sesuai dengan jenis gaunnya),

2. Ukuran gaun perlindung harus cukup panjang dan dapat menutupi seragam perawat bagian depan dan belakang namun tidak menutupi lengan,

3. Jika menggunakan seragam lengan panjang, seragam harus digulung diatas siku dan perawat baru menggunakan gaun pelindung,

4. Ketika hendak melepaskan gaun pelindung, cara melepaskan adalah dari dalam keluar untuk mencegah kontaminasi cairan dengan seragam, Setelah melepas gaun jangan lupa untuk selalu mencuci tangan sebelum melakukan aktivitas lain.

5. Alas kaki (sepatu)

Alas kaki merupakan bagian dari APD yang perlu untuk digunakan. Alas kaki melindungi perawat ataupun petugas kesehatan terhadap tumpuhan atau percikan darah maupun cairan tubuh 
yang lain. Penggunaan alas kaki juga bertujuan untuk mencegah kemungkinan tusukan benda tajam maupun kejatuhan alat kesehatan (Depkes, 2003). Menurut Rosdahl \& Merry (2008) yang dikutip Putra (2012), standar alas kaki yang tertutup seluruh ujung jari dan telapak kaki serta terbuat dari bahan yang mudah dicuci dan bahan tusukan. Penggunaan alas kaki termsuk juga sepatu yang dipakai sehari-hari harus memenuhi syarat dan juga penggunaan sepatu khusus seperti sepatu khusus diruang tertentu misal ruang operasi, ICU, isolasi, ruang bersalin, ruang pemulasaraan jenazah (Depkes, 2003).

Prosedur Kerja K3 di rumah sakit digunakan untuk melindungi perawat. Pada dasarnya perawat di Rumah Sakit Permata Bunda sudah mengetahui tujuan dan manfaat jika mereka menerapkan prosedur kerja dengan baik, seperti mengurangi kesalahan atau kegagalan dalam proses kerja. Namun, beberapa dari perawat masih ada yang belum memiliki kesadaran untuk menerapkan prosedur kerja dalam melakukan pekerjaannya karena belum ada sanksi yang tegas, hanya berupa teguran saja, ada juga pekerja merasa terbebani dengan beberapa prosedur kerja, dan ada juga menyatakan prosedur kerja membuat pekerjaan merela lebih lambat.

\section{Pengendalian Risiko}

Berdasarkan identifikasi bahaya upaya pengendalian risiko untuk aktivitas kerja di ruang Pangeran Suryanegara (Psikiatri) dengan lima hirarki pengendalian yaitu:

1. Melakukan perawatan terhadap pasien pada siang hari Substitusi: Gunakan pencahayaan yang baik, agar penglihatan dapat melihat dengan jelas pada objek

2. Melakukan pembersihan ruangan Administrasi: Memperhatikan tanda-tanda peringatan yang ada di lokasi kerja untuk mengatisipasi adanya bahaya dan melakukan pekerjaan sesuai dengan prosedur.

3. Melakukan perawatan pada penderita penyakit menular APD: Alat pelindung diri perawat menggunakan sarung tangan dan masker ketika melakukan tindakan terhadap pasien.

4. Melakukan restrain Administrasi: Dilakukan manajemen kerja dengan pelatihan perawat untuk penanganan pada pasien gangguan jiwa. Merestrain pasien ketika mengamuk, dan mengisolasi pasien pada saat gaduh-gelisah.

5. Memandikan pasienTeknik: Pekerjaan yang dilakukan berulang-ulang bisa menguras tenaga, dengan tambahan petugas atau gunakan bantuan mesin.

6. Mengganti pakaian pasien Administrasi: Harus melakukan tata cara yang baik dalam SOP/SPO ergonomi yang baik dan benar.

7. Dinas malam yang melebihi 8 jam Administrasi: Melakukan manajemen kerja untuk menghindari beban tugas yang terlalu padat.

8. Menangani pasien halusinasi Eliminasi: Menghilangkan rasa takut pada pekerjaan yang membuat psikologi terganggu saat bekerja.

9. Menangani pasien yang defisit perawatan diri (melatih BAB \& BAK) Administrasi: Memahami tata cara dalam melakukan pekerjaan dan pelatihan keperaawatan jiwa bagi perawat.

10.Melakukan terapi bermain/ TAK Administrasi: Memahami tata cara dalam melakukan pekerjaan alat dengan fisik agar bisa meningkatkan kesejahteraan fisik, mental, dan beban kerja. Pelatihan keperawatan jiwa bagi perawat. 


\section{Penutup}

Penggunaan alat pelindung diri (APD) lengkap dengan cara yang benar dapat menurunkan angka kejadian cedera di kamar operasi, sehingga perlu adanya pengadaan APD standar dan sosialisasi penggunaannya kepada perawat. Guna meningkatkan kepatuhan perawat dalam menerapkan pedoman keselamatan kerja untuk mengurangi angka kejadian cedera, diharapkan adanya pelatihan terkait kesehatan dan keselamatan kerja rumah sakit berkala setiap enam bulan agar peningkatan perilaku kesehatan dan keselamatan kerja dapat bersifat permanen. Perlu dilakukan supervisi berkala setiap bulan untuk mengecek kepatuhan perawat menerapkan standar prosedur operasional yang berlaku di ruangan, sehingga dapat dilakukan evaluasi pedoman yang belum patuh dilaksanakan.

1. Untuk mempertahankan beban kerja fisik pekerja dengan kategori ringan adalah mengurangi jam lembur pekerja, tidak ada penambahan jam selain jam kerja.

2. Perlu dilakukan peningkatan

pengetahuan $\mathrm{K} 3$ pada pekerja dengan cara menambah wawasan atau ilmu tentang $\mathrm{K} 3$ pada pekerja dan diberikan pelatihan-pelatihan yang berhubungan dengan K3.

3. Untuk mempertahankan sikap K3 pekerja dengan kategori baik adalah memberikam motivasi atau dorongan untuk selalu memperhatikan $\mathrm{K} 3$ yang diawasi oleh team leader.

4. Perlu melakukan penelitian penerapan Kesehatan dan Keselamatan Kerja (K3) terhadap faktor lingkungan kerja dan faktor alat dan mesin kerja.

\section{Daftar Pustaka}

1. Azizah, N., Setiawan., \& Gerry S. (2018). Hubungan Antara Pengawasan, Prosedur Kerja Dan Kondisi Fisik Dengan Terjadinya Kecelakaan Kerja Pada Perawat Di Ruang Rawat Inap RUMAH SAKITPERMATA BUNDA MEDAN TAHUN 2017. Jurnal Jumantik, 3(2), 125-134.

2. Hanifa, N D., Titik R., \& Yuli S. (2017). Hubungan Pengetahuan dengan Upaya Penerapan K3 pada Perawat. 1(1), 144-149.

3. Hasugian, A R. (2017). Perilaku Pencegahan Penyakit Akibat Kerja Tenaga kerja Indonesia di Kansashi, Zambia Analisis Kualitatif. Jurnal media Litbangkes, 27(2), 111-124.

4. Indragiri, S. (2018). Manajemen Risilo K3 Menggunakan Hazard Identification Risk Assessment Anda Risk Control (HIRARC). Jurnal Kesehatan, 9(1), 39-52.

5. Laranova, A., Afriandi, I., \& Pratiwi, Y. S. (2018). Persepsi Tenaga Kesehatan terhadap Penggunaan Alat Pelindung Diri dan Kejadian Kecelakaan Akibat Kerja di Salah Satu Rumah Sakit di Kota Bandung. Jurnal Sistem Kesehatan, 3(4).

6. Octavia, W R., A.T D N., \& Ernita S. (2018). Penerapan Pelayanan Kesehatan Dan Keselamatan Kerja Pada Perawat IGD RUMAH SAKIT UMUM DR.WAHIDIN SUDIRO HUSODO MOJOKERTO TAHUN 2017. Jurnal Gema Kesehatan Lingkungan, 16(1), 101-109.

7. Pitoyo, J., Rudi H., \& Titis E S. (2017). Kepatuhan Perawat Menerapkan Pedoman Keselamatan Kerja Dan Kejadian Cedera Pada Perawat Instrumen Di Jurnal Media Instalasi Bedah Sentral. Jurnal Pendidikan Kesehatan, 6(2), 65-70

8. Salawati, L. (2015). Penyakit Akibat Kerja dan Pencegahan.Jurnal Kedokteran Syiah Kuala, 15(2), 91-95.

9. Simamora, R. H. (2020). Pelatihan Komunikasi Efektif untuk Meningkatkan Efikasi diri Perawat dalam Pelaksanaan Identifikasi Pasien. JURNAL ILMIAH KESEHATAN MASYARAKAT: Media Komunikasi Komunitas Kesehatan Masyarakat, 12(1), 49-54.

10. Simamora, R. H. (2011). ROLE CONFLICT OF NURSE RELATIONSHIP WITH PERFORMANCE IN THE EMERGENCY UNIT OF HOSPITALS RSD DR. SOEBANDI JEMBER. The Malaysian Journal of Nursing, 3(2), 23-32. 
11. Sudarmo., Zairin N H., \& Lenie M. (2016). Faktor Y ang Mempengaruhi Perilaku Terhadap Kepatuhan Penggunaan Alat Pelindung Diri (APD) Untuk Pencegahan Penyakit Akibat Kerja. Jurnal Berkala Kesehatan, 1(2), 88-95.

12. Suharto. \& Ratna S. (2016). Hubungan Pengetahuan Dan Sikap Perawat Dengan Tindakan Pencegahan Infeksi Di Ruang ICU RUMAH SAKIT. Jurnal Riset Hesti Medan, 1(1), 1-9. 